\title{
Tidal coupling between carbohydrate concentrations and bacterial activities in diatom-inhabited intertidal mudflats
}

\author{
Fleur C. van Duyl ${ }^{1, *}$, Ben de Winder ${ }^{2, * *}$, Arjen J. Kop ${ }^{1}$, Ute Wollenzien ${ }^{3}$ \\ ${ }^{1}$ Netherlands Institute for Sea Research (NIOZ), PO Box 59, 1790 AB Den Burg, Texel, The Netherlands \\ ${ }^{2}$ Amsterdam Research Institute for Substances in Ecosystems, Microbiology, Nieuwe Achtergracht 127, 1018 WS Amsterdam, \\ The Netherlands \\ ${ }^{3}$ Netherlands Institute of Ecology, Centre of Estuarine and Coastal Ecology (NIOO-CEMO), PO Box 140, 4400 AC Yerseke,
} The Netherlands

\begin{abstract}
Sediment bacterial production, abundance and $\beta$-glucosidase activity were studied in relation to carbohydrate concentrations in diatom-inhabited intertidal mudflats during the tidal cycle in the Ems-Dollard estuary in summer 1996. During the diurnally emerged period significant increases in water-and EDTA-extracted carbohydrates, bacterial production and abundance in the sediment surface layer ( 0 to $2 \mathrm{~mm}$ ) were established. Exposure had no effect on algal biomass (chlorophyll a), doubling times of bacteria or $\beta$-glucosidase activity in the surface layer. Net changes in water-extracted carbohydrates together with net changes in total and CTC (5-cyano-2,3-ditolyl tetrazolium chloride)stained bacteria accounted for $85 \%$ of the variations in net increase in bacterial production during the emerged period. During the submerged period significant decreases of water-extracted carbohydrate concentrations occurred. The changes in $\beta$-glucosidase activity and water-extracted carbohydrates could explain $93 \%$ of the net changes in bacterial production during the submerged period. Waterextracted carbohydrates derived mainly from live diatoms. The source of EDTA-extracted carbohydrates was less specific, but related to chlorophyll $a$ and pheopigments. The results suggest that the net increases in water-extracted carbohydrates due to diatom activities are indirectly coupled to benthic heterotrophic bacterial production. Bacteria do respond to tidal variations in organic compounds, and water-extracted carbohydrates are an important indicator.
\end{abstract}

KEY WORDS: Extracellular polymeric substances Carbohydrates - Benthic bacterial production Bacterial abundance $\cdot \beta$-glucosidase activity Cohesive sediments - Diatoms - Ems-Dollard estuary

\section{INTRODUCTION}

Extracellular polymeric substances (EPS) are important for biostabilization processes (Underwood \& Paterson 1993a, b, Paterson et al. 1994, Yallop et al. 1994) and for the C-flow in sediments (for reviews see Decho 1990, Meyer-Reil 1994). EPS, usually dominated by carbohydrates, may act as an important vehicle for carbon cycling and as a $\mathrm{C}$-source for microbes and deposit-feeding invertebrates (e.g. Decho \& Moriarty

\footnotetext{
•E-mail: duyl@nioz.n]

- Present address: National Institute for Coastal and Marine Management, PO Box 8039, 4330 EA Middelburg, The Netherlands
}

1990, Decho \& Lopez 1993). In many intertidal cohesive-sediment habitats dominated by epipelic diatoms, colloidal carbohydrate concentrations are related to chlorophyll a (chl a) concentrations (Underwood \& Smith 1998), which links these saccharides to the phototrophic community. Secretion of carbohydrates by benthic diatoms is a function of the physiological state of the algae and the environmental factors (Paterson 1989, Underwood \& Paterson 1993a, b, Wetherbee et al. 1998). During the emerged period of diatom-inhabited intertidal flats, increases in EPS can be detected, and based on field data a range in net production rates of 80 to $500 \mathrm{ng}$ EPS (as glucose equivalents) $\mu \mathrm{g} \mathrm{chl} \mathrm{a}^{-1} \mathrm{~h}^{-1}$ during illumination periods have been reported by Underwood \& Smith (1998). 
Hardly anything is known about the fate of carbohydrates in intertidal sediments. Speculations about losses of EPS to the water column after submersion or to heterotrophic growth of diatoms in the dark have not been corroborated as yet and studies examining the bacterial breakdown and utilisation of sediment EPS are few (Admiraal 1984, Decho \& Moriarty 1990). Relations between benthic bacterial distribution and total carbohydrates have been reported (Danovaro et al. 1993). Growth of bacteria on sediment poly/oligosaccharides has been indirectly addressed in studies of bacterial production and potential glucosidase activities with fluorogenic substrates (Meyer-Reil 1986, Poremba \& Hoppe 1995). To decompose structural polysaccharides, hydrolysis of $(1,4)$ - $\beta$-glucosidic bonds, which predominate in mucopolysaccharides in EPS (Herndl \& Peduzzi 1989, Boetius 1995), is required by $\beta$-glucanases, splitting polysaccharides into smaller fractions, and by $\beta$-glucosidase, splitting disaccharides into monosaccharides (Ljungdahl \& Eriksson 1985). For structural saccharide decomposition $\beta$-glucosidases, i.e. ectoenzymes associated with bacteria, are presumed to form the rate-limiting step (Billen 1982, Meyer-Reil 1990). Induction of $\beta$-glucosidase production appears to be proportional to the supply of structural polysaccharides in deep-sea sediments (Boetius \& Lochte 1994). The activity of this enzyme may reflect variations in the availability of its substrates. The products of glucosidase activity, e.g. glucose, are rapidly used by benthic bacteria (e.g. Sawyer \& King 1993). Pearl et al. (1993) found light-stimulated dissolved organic matter (DOM) uptake by heterotrophic bacteria associated with mucus in microbial mats. Whether this can be demonstrated on time scales of hours, relevant for tidal dynamics in diatom-inhabited mudflats, is so far unknown.

We aim to obtain a clearer insight into the functional role of extracellular carbohydrates in benthic heterotrophic bacterial dynamics. Focus was put on bacterial activities in relation to variation in several fractions of carbohydrates in diatom-inhabited intertidal sediments over the tidal cycle, particularly during but also between emerged periods. We hypothesize that stimulated carbohydrate production during tidal emersion enhances $\beta$-glucosidase activity and heterotrophic bacterial production in diatom-inhabited intertidal mudflats.

\section{MATERIAL AND METHODS}

Study site and sampling frequency. The study was carried out on an intertidal mudflat, the Heringsplaat, in the Ems-Dollard estuary (Fig. 1) in June/July 1996. To restrict the spatial heterogeneity all sampling took

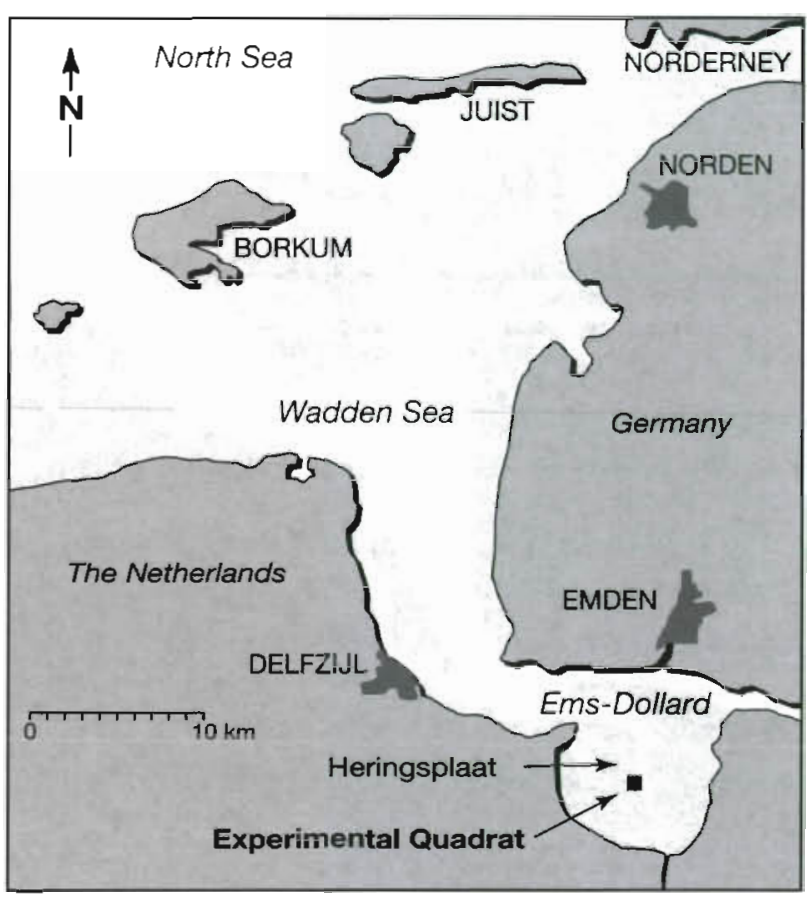

Fig. 1. Location of the study area in the Ems-Dollard, an estuary at the Dutch-German border. The position of the experimental quadrat on an intertidal mudflat (Heringsplaat) is indicated

place in an experimental quadrat (EQ) of $10 \times 10 \mathrm{~m}$ (co-ordinates $53^{\circ} 17.000^{\prime} \mathrm{N}, 07^{\circ} 09.370^{\prime} \mathrm{E} ; 20$ to $30 \mathrm{~cm}$ above NAP [Netherlands Ordnance Datum]). The quadrat was located in the middle of a 120 to $150 \mathrm{~m}$ wide diatom mat zone, which ran parallel to the adjacent main tidal channel. Sediment samples were collected immediately after the water receded from the sediment, defined as 'beginning of emerged period' and just before the sediment was flooded, defined as 'end of emerged period'. The emerged or exposed period lasted on average 5 to $6 \mathrm{~h}$. Altogether 9 emerged periods (including 2 partly in the dark) were sampled between 26 June and 10 July 1996 (see Table 1, emerged period).

To study the changes in variables during the submerged period we compared variables at the end of an emerged period with variables at the beginning of the next sampled emerged period (Table 1, 'submerged' period). The time interval between these measurements covered between 1 and 4 submerged periods and always covered more submerged periods, by 1 , than emerged periods. Due to cruise logistics it was only once possible to sample a singular submerged period (26 June). Therefore the 'submerged' period refers to a period of up to $45 \mathrm{~h}$ in which the submerged time exceeded the emerged time period at the EQ by 6 to $7 \mathrm{~h}$.

Sediment sampling. During each exposure period a $2 \mathrm{~m}^{2}$ lot of undisturbed sediment in the EQ was used 
Table 1. Time schedule of sampling (CET) and elapsed time intervals over the emerged and 'submerged' periods (for explanation see text)

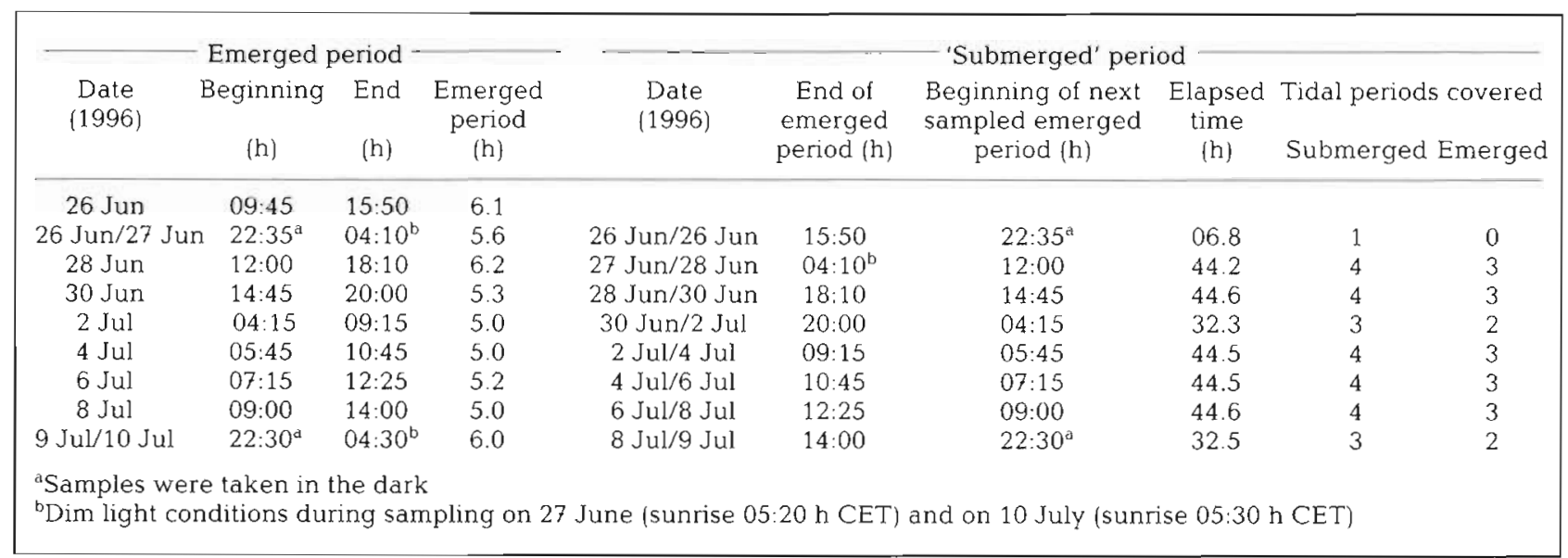

for sediment collection. The remainder of the quadrant was disturbed as little as possible. Routinely, temperatures were measured in the sediment surface layer before sediment collection. Biochemical and microbial variables were sampled in the 0 to $2 \mathrm{~mm}$ sediment surface layer and in the 10 to $12 \mathrm{~mm}$ layer as reference depth, where direct variations due to illumination and aerial exposure are not likely to occur. Stainless steel tubes (inner diameter [i.d.] $17.4 \mathrm{~mm}$ ) and acrylic liners (i.d. $25 \mathrm{~mm}$ ) of $15 \mathrm{~cm}$ length were pushed into the sediment, stoppered and pulled/turned out. Sediment cores were sliced on board within $40 \mathrm{~min}$. For each sampling, 5 slices from 0 to $2 \mathrm{~mm}$ depth and 5 from 10 to $12 \mathrm{~mm}$ depth were stored at $-20^{\circ} \mathrm{C}$ and analysed separately ( 5 replicates). After sediment wet weight determination, samples were freeze dried and analysed for sediment dry weight, carbohydrates and phytopigments. Sediment porosity was measured on the basis of weight $(w / w \%)$ and on the basis of volume $(\mathrm{v} / \mathrm{v} \%$ ). The dry mass density of the wet sediment $(\mathrm{kg}$ $\mathrm{m}^{-3}$ ) was estimated on the basis of the average volume of sediment slices. For bacterial variables (benthic bacterial production, bacterial abundance and $\beta$-glucosidase activities) 2 sediment slurries were prepared from. 10 to 15 sediment cores, 1 of pooled sediment surface slices ( 0 to $2 \mathrm{~mm}$ ) and 1 of pooled slices from 10 to $12 \mathrm{~mm}$ depth, by adding $10 \mathrm{ml}$ wet sediment to $10 \mathrm{ml}$ of $0.2 \mu \mathrm{m}$ filtered sea water.

Carbohydrate analyses. The water- and EDTA-soluble carbohydrates were determined in the sediment with the water extraction method for soluble carbohydrates and the EDTA extraction method for more strongly bound carbohydrates such as uronic acids. Freeze-dried sediment ( 400 to $500 \mathrm{mg}$ ) was mixed with $1 \mathrm{ml}$ distilled water and incubated for $1 \mathrm{~h}$ at $30^{\circ} \mathrm{C}$. Subsequently the sample was spun in an Eppendorf centrifuge at $10000 \times g$ ). The supernatant was separated from the pellet, transferred into a clean vial and referred to as water-extract. To $200 \mu$ l supernatant $1.5 \mathrm{ml}$ ethanol $(96 \%)$ was added and the sample was incubated for $12 \mathrm{~h}$ at $-20^{\circ} \mathrm{C}$ to precipitate the polymeric fraction and subsequently the sample was centrifuged. This supernatant and the pellet were separated and dried with $\mathrm{N}_{2}$. Subsequently, the phenolsulfuric acid assay (Herbert et al. 1971) was applied to the supernatant for low molecular weight (LMW) carbohydrates and to the suspended pellet for high molecular weight (HMW) carbohydrates. This HMW fraction can be considered as EPS (sensu Underwood et al. 1995), consisting of mucopolysaccharides. The pellet was incubated with $1.5 \mathrm{ml}$ EDTA $(100 \mathrm{mM}$ final concentration) for $12 \mathrm{~h}$ at room temperature and subsequently centrifuged. The supernatant with the colloidal EDTA was transferred to a clean vial and, if needed, diluted before the phenol-sulfuric acid assay was applied. The absorbance was measured with a colorimeter against a reagent blank at $488 \mathrm{~nm}$ (Herbert et al. 1971). Calibration was via a standard curve of absorption versus glucose concentration to give results in $\mu g$ glucose equivalents (glu. equ.).

Phytopigment analyses. The chl a and pheopigments were determined in freeze-dried sediment (dry weight ca $200 \mathrm{mg}$ minimum) which was mixed with $1.5 \mathrm{ml}$ dimethylformamide (DMFA) (De Winder et al. 1999). The mixture was incubated in the dark for at least $1 \mathrm{~h}$, after which the sample was vortexed and centrifuged. The chl a absorption in the supernatant was measured spectrophotometrically at $665 \mathrm{~nm}$. Subsequently the supernatant was acidified with $10 \mu \mathrm{l} 4 \mathrm{~N}$ $\mathrm{HCl}$, mixed and measured again for determination of pheopigments. Carbohydrate and pigment concentrations were measured in $\mu \mathrm{g} \mathrm{g}^{-1}$ dry sediment and converted to $\mu \mathrm{g} \mathrm{cm}^{-3}$ wet sediment based on the volume of the sediment slices analysed. 
Bacterial variables. Bacterial production was measured with the ${ }^{3} \mathrm{H}$-leucine incorporation method (Kirchman et al. 1986, Simon \& Azam 1989) following the procedure for sediments (Moriarty 1990) with a few adaptations (Van Duyl \& Kop 1994). Sediment slurry aliquots of $200 \mu \mathrm{l}$ were incubated with increasing concentrations of leucine $(0.2,0.4,0.6 \mathrm{nmol}$ per $200 \mu \mathrm{l}$ respectively) containing $0.02 \mathrm{nmol}$ labelled leucine (L- $\left[4,5-{ }^{3} \mathrm{H}\right]$ leucine, Amersham) supplemented with cold leucine. This way isotope dilution was determined routinely in all slurries, normalizing each sample with its dilution factor (Moriarty \& Pollard 1981). Incubations were performed in the dark at $15^{\circ} \mathrm{C}$. In the controls, bacterial production was stopped at $t=0$ and in the experimental samples at $t=30 \mathrm{~min}$ by adding $10 \mathrm{ml}$ $80 \%$ ethanol. Radioactivity was counted on a RackBeta liquid scintillation counter. The equation and conversion factors used for the calculation of benthic bacterial production (BBP) are described in detail by Van Duyl \& Kop (1994). For preparation of bacterial count samples $1 \mathrm{ml}$ sediment slurry was fixed with $50 \mu \mathrm{l}$ of $0.2 \mu \mathrm{m}$ filtered borate buffered $37 \%$ formaldehyde and stored at $4^{\circ} \mathrm{C}$ until processing. Storage of sediment samples did not influence the total counts. After sonification bacteria were stained with Acridine Orange and counted with an epifluorescent microscope (Hobbie et al. 1977, Van Duyl \& Kop 1994). Actively respiring bacteria were determined with the tetrazolium salt 5-cyano-2,3-ditolyl tetrazolium chloride (CTC) (Rodriguez et al. 1992). To $1 \mathrm{ml}$ sediment slurry $80 \mu \mathrm{l} \mathrm{CTC}$ was added (final concentration ca $4 \mathrm{mM}$ ). Samples were incubated for up to $5 \mathrm{~h}$ in a shaking waterbath at field temperature. Incubations were stopped with $50 \mu \mathrm{l}$ of $0.2 \mu \mathrm{m}$ filtered borate buffered formaldehyde. Slides for enumeration of fluorescent actively respiring bacteria were prepared within $7 \mathrm{~d}$ after the incubations and epifluorescent microscopically scanned within $14 \mathrm{~d}$ after the cruise. Under green excitation CTC-stained cells fluoresce bright red. Effects of different storage times were not found.

Doubling times of bacteria were determined by $\ln 2 / \mu . \mu$ refers to the specific growth rate of bacteria and is calculated by dividing bacterial production by the number of bacteria (total count and CTC-stained bacteria).

Measurement of exoenzymatic activity by means of methylumbelliferyl (MUF)-substrates was first applied to natural samples by Hoppe (1983) and Somville \& Billen (1983). To estimate the potential $\beta$-glucosidase activity $\left(V_{m}\right)$ in sediments, 40 to $80 \mu \mathrm{l}$ methylumbelliferone (MUF) $\beta$-glucoside substrate was added to $1 \mathrm{mI}$ sediment slurry (the final concentration of 1 to $2 \mathrm{mM}$ was saturating the enzyme activity) (Boetius \& Lochte 1994). $V_{m}$ is an indirect measure of the enzyme concentration available for cleavage of the specific sub- strate. In time series samples were incubated for 0,30 and 60 min respectively at field temperature in a shaking water bath. The enzyme activity was stopped by diluting the sample with $250 \mu$ l borate buffer $(\mathrm{pH}=10$ ) and $2250 \mu \mathrm{l} 0.2 \mu \mathrm{m}$ filtered seawater and the sample was transferred to a temperature-controlled waterbath at $0^{\circ} \mathrm{C}$ until samples were centrifuged for $30 \mathrm{~min}$ at $2^{\circ} \mathrm{C}$. The fluorescence in the supernatant was immediately measured at $365 \mathrm{~nm}$ excitation and $455 \mathrm{~nm}$ emission on a spectrofluorometer. The enzyme activities were calibrated by standard additions of MUF.

Statistics. All statistical analyses were done with SYSTAT (Wilkinson 1989). $t$-tests were conducted to establish differences between values of variables at the beginning and at the end of the emerged period and to assess differences in variables with depth in the sediment. Pearson correlation tests were done with parts of and the complete data set without and with adjustment (Bonferroni correction) to the probability for multiple testing (Rice 1989). Analyses of variance (ANOVA) were run with the absolute changes in variables over emerged and submerged periods.

\section{RESULTS}

\section{The abiotic environment}

Air temperature during the cruise varied from 10 to $19^{\circ} \mathrm{C}$, with a water temperature around $15^{\circ} \mathrm{C}$. The sediment surface temperature during the emerged periods varied from 12 to $20^{\circ} \mathrm{C}$ and increased on 5 and decreased on 4 occasions of the 9 emerged periods sampled. Dry mass density ranged from 300 to $1200 \mathrm{~kg}$ $\mathrm{m}^{-3}$ in the 0 to $2 \mathrm{~mm}$ surface layer but did not significantly change either during the tidal cycle (Fig. 2a, Table $2 a, b)$ or with depth. The high variance is due to the inaccuracy in measuring the exact volume of wet sediment slices and the extrapolation of the weight measurements from $0.48 \mathrm{~cm}^{3}$ to $1 \mathrm{~m}^{3}$. The porosity ( $\mathrm{v} / \mathrm{v} \%$ ) was measured 5 times during emerged periods and was on average $82 \pm 6 \%$ in the $2 \mathrm{~mm}$ surface layer of the diatom mat and $64 \pm 6 \%$ in the 10 to $12 \mathrm{~mm}$ sediment layer. In the sediment surface layer the porosity on weight basis ( $w / w \%)$ dropped slightly but significantly during the emerged period, on average from 66.4 to $63.2 \%$ which corresponds to a decrease of $5 \pm$ $3.5 \%$ (Fig. 2b). This decrease was recorded neither deeper in the sediment nor during the submerged period (Table $2 \mathrm{a}, \mathrm{b}$ ). With depth in the sediment, the porosity $(w / w \%)$ also significantly dropped ( $t$-test, $n=$ 8, $\mathrm{p}<0.05$ ). Most likely, a water film was incorporated in the surface samples at the beginning of the emerged period of the tidal flat which was not there 5 to $6 \mathrm{~h}$ later just before inundation at the end of the emerged 
Fig. 2. Comparisons of (a) dry mass density and (b) sediment porosity at the beginning of the emerged period with their values at the end of the emerged period $(\mathrm{n}=9)$. Circles: comparisons at 0 to $2 \mathrm{~mm}(\mathrm{n}=9,7$ daytime [O] and 2 nighttime [ $\otimes]$ emerged periods); ( 4 comparisons at the reference depth, 10 to $12 \mathrm{~mm}(\mathrm{n}=4)$. Diagonal line eases reading of the plot. Data points in the upper left part: variable increased over the emerged period; in the lower right part: variable decreased over the emerged period. Data points on the line: no change over the emerged period
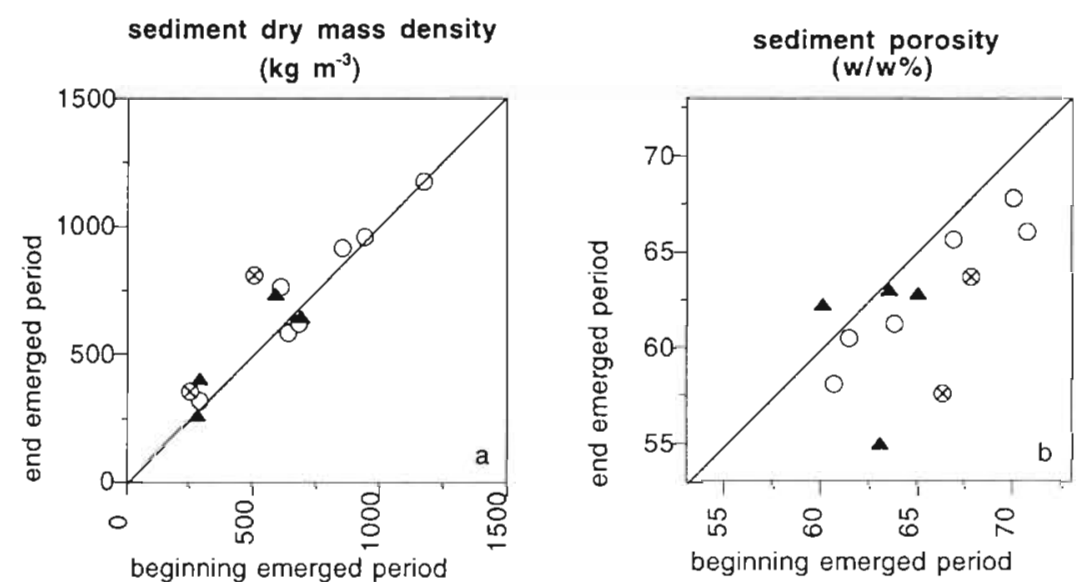

period. The surface sediment samples taken at the beginning of the emerged period were therefore slightly wetter than the samples taken at the end of this period. Thus, the sampling scheme (day-or nighttime) did not affect the changes observed in the different variables over the emerged period.

Table 2. Results of the paired $t$-tests. (a) Values of variables at the beginning of the emerged period were tested against values at the end of the emerged period ( 5 to $6 \mathrm{~h}$ later) for the 0 to $2 \mathrm{~mm}$ layer $(\mathrm{n}=9)$ and for the reference depth, 10 to $12 \mathrm{~mm}$ below the diatom mat $(n=4)$. (b) Values of variables at the end of the emerged period were tested against values at the beginning of the next measured emerged period (taken 5 to $6 \mathrm{~h}$ up to $45 \mathrm{~h}$ later) for the 0 to $2 \mathrm{~mm}$ layer. Mean differences (mean diff.) and $t$-values were positive when values increased over the emerged period. On average significant differences: $\cdots p<0.01, \cdot p<0.05$ levels. ns: not significant. ( $($ ) the average difference is significant at $p<0.05$, but the standard deviation (SD diff.) exceeds the mean difference. HMW, LMW: high and low molecular weight, respectively. CTC: cyano-2,3-ditolyl tetrazolium chloride

\begin{tabular}{|c|c|c|c|c|c|c|c|c|c|c|}
\hline \multirow[t]{2}{*}{ Variable } & \multicolumn{5}{|c|}{ Diatom mat 0 to $2 \mathrm{~mm} \longrightarrow$} & \multicolumn{5}{|c|}{ Diatom mat 10 to $12 \mathrm{~mm}-$} \\
\hline & Mean diff. & SD diff. & $t$ & $d f$ & $\mathrm{p}$ & Mean diff & SD diff. & $t$ & df & $\mathrm{p}$ \\
\hline \multicolumn{11}{|l|}{ (a) Emerged period } \\
\hline Sediment dry mass density $\left(\mathrm{kg} \mathrm{m}^{-3}\right)$ & 62.7 & 114.9 & 1.636 & 8 & ns & 51.5 & 96.3 & 1.069 & 3 & ns \\
\hline Sediment porosity $(w / w \%)$ & -3.211 & 2.373 & -4.060 & 8 & •. & -2.098 & 4.3 & -0.968 & 3 & ns \\
\hline Water-extracted HMW carbohyd. ( $\mu \mathrm{g} \mathrm{cm}^{-3}$ wet sed.) & 107.1 & 102.6 & 3.133 & 8 & $\cdot$ & -10.3 & 37.4 & -0.548 & 3 & ns \\
\hline Water-extracted LMW carbohyd. ( $\mu \mathrm{g} \mathrm{cm}^{-3}$ wet sed.) & 230.9 & 124.6 & 5.558 & 8 & $\because$ & 14.6 & 40.1 & 0.729 & 3 & ns \\
\hline EDTA-extracted carbohyd. ( $\mu \mathrm{g} \mathrm{cm}^{-3}$ wet sed.) & 157.0 & 130.1 & 3.621 & 8 & .. & -38.4 & 68.5 & -1.121 & 3 & ns \\
\hline 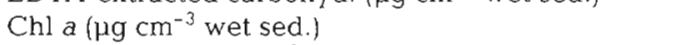 & 5.8 & 16.5 & 1.059 & 8 & ns & -0.475 & 2.540 & -0.374 & 3 & ns \\
\hline Pheopigment ( $\mu \mathrm{g} \mathrm{cm}^{-3}$ wet sed.) & 3.9 & 10.3 & 1.129 & 8 & ns & 0.475 & 7.967 & 0.119 & 3 & ns \\
\hline Benthic bact. production $\left(\mu \mathrm{gC} \mathrm{cm}^{-3}\right.$ wet sed. $\left.\mathrm{h}^{-1}\right)$ & 5.1 & 4.3 & 3.567 & 8 & $\ddot{*}$ & 0.8 & 1.5 & 1.052 & 3 & $\mathrm{~ns}$ \\
\hline Bacterial abundance ( $\mathrm{cm}^{-3}$ wet sed.) & 0.673 & 0.514 & 3.927 & 8 & $\because$ & 0.837 & 0.972 & 1.723 & 3 & ns \\
\hline CTC-stained bacteria ( $\mathrm{cm}^{-3}$ wet sed.) & 0.292 & 0.340 & 2.575 & 8 & $\cdot$ & 1.041 & 0.525 & 4.000 & 3 & $\cdot$ \\
\hline Doubling time total bacteria $(\mathrm{h})$ & -1.499 & 1.963 & -2.29 & 8 & ns & -7.555 & 16.969 & -0.890 & 3 & ns \\
\hline Doubling time CTC-stained bacteria $(\mathrm{h})$ & 0.005 & 0.286 & 0.051 & 8 & ns & 2.789 & 1.252 & 4.455 & 3 & $\cdot$ \\
\hline$\beta$-glucosidase activity (nmol $\mathrm{cm}^{-3}$ wet sed. $\mathrm{h}^{-1}$ ) & 1.011 & 4.827 & 0.628 & 8 & ns & 3.895 & 1.494 & 5.214 & 3 & • \\
\hline$\beta$-glucosidase activity (nmol bact. ${ }^{-1} \mathrm{~h}^{-1}$ ) & $<-10^{-9}$ & $10^{-9}$ & -0.047 & 8 & ns & $<-10^{-9}$ & $<10^{-9}$ & 1.880 & 3 & ns \\
\hline \multicolumn{11}{|l|}{ (b) Submerged period } \\
\hline Sediment dry mass density $\left(\mathrm{kg} \mathrm{m}^{-3}\right)$ & 5.2 & 255.7 & 0.058 & 7 & ns & & & & & \\
\hline Sediment porosity (w/w $\%)$ & -2.068 & 5.172 & -1.131 & 7 & ns & & & & & \\
\hline Water-extracted HMW carbohyd. ( $\mu \mathrm{g} \mathrm{cm}^{-3}$ wet sed.) & 92.43 & 111.0 & 2.356 & 7 & $(\cdot)$ & & & & & \\
\hline Water-extracted LMW carbohyd. ( $\mu \mathrm{g} \mathrm{cm}^{-3}$ wet sed.) & 205.9 & 1.66 .6 & 3.707 & 7 & $\because$ & & & & & \\
\hline EDTA-extracted carbohydrates ( $\mu \mathrm{g} \mathrm{cm}^{-3}$ wet sed.) & 116.5 & 146.8 & 2.245 & 7 & ns & & & & & \\
\hline Chl a ( $\mu \mathrm{g} \mathrm{cm}^{-3}$ wet sed.) & -0.75 & 22.28 & -0.095 & 7 & ns & & & & & \\
\hline Pheopigment ( $\mu \mathrm{g} \mathrm{cm}^{-3}$ wet sed.) & 2.26 & 12.04 & 0.532 & 7 & ns & & & & & \\
\hline Benthic bact. production ( $\mu \mathrm{g} \mathrm{C} \mathrm{cm}^{-3}$ wet sed. $\mathrm{h}^{-1}$ ) & 3.70 & 4.47 & 2.372 & 7 & $(*)$ & & & & & \\
\hline Bacterial abundance ( $\mathrm{n} \mathrm{cm}^{-3}$ wet sed.) & 0.648 & 0.992 & 1.848 & 7 & ns & & & & & \\
\hline CTC-stained bact. (n $\mathrm{cm}^{-3}$ wet sed.) & 0.272 & 0.172 & 4.465 & 7 & $\cdot$ & & & & & \\
\hline Doubling time total bacteria $(\mathrm{h})$ & -1.40 & 2.32 & -1.709 & 7 & ns & & & & & \\
\hline Doubling time CTC-stained bacteria $(\mathrm{h})$ & 0.003 & 0.269 & 0.034 & 7 & ns & & & & & \\
\hline 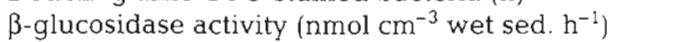 & 1.74 & 4.35 & 1.131 & 7 & ns & & & & & \\
\hline$\beta$-glucosidase acttivity (nmol bact. ${ }^{-1} \mathrm{~h}^{-1}$ ) & $<10^{-9}$ & $10^{-9}$ & 0.388 & 7 & ns & & & & & \\
\hline
\end{tabular}




\section{Changes during the emerged period}

The $5 \%$ decrease in water content of the surface sediment over the emerged period could not account for the established increases in biochemical and microbial variables mentioned below (ANOVA; not significant). Therefore, differences in water content between samples were ignored in the further analysis. The increase in water-extracted HMW carbohydrates during the emerged period was statistically significant (Fig 3a, Table $2 a$ ). On average these polysaccharides increased by $55 \%$, with a net production rate of $19.4 \mu \mathrm{g}$ glu. equ. $\mathrm{cm}^{-3}$ wet sed. $\mathrm{h}^{-1}\left(7.8 \mu \mathrm{g} \mathrm{C} \mathrm{cm}^{-3} \mathrm{~h}^{-1}\right)$. Polymer concentrations at 10 to $12 \mathrm{~mm}$ under the diatom mat were significantly lower than in the surface $2 \mathrm{~mm}$ ( $t$-test, $\mathrm{n}=8$, $p<0.01$ ) and did not show variations due to exposure (Table 2a). The concentration of the water-extracted LMW carbohydrate fraction in the surface sediment showed significant increases during the emerged period even stronger than those of the HMW carbohydrates (Fig. 3b, Table 2a). The LMW fraction almost doubled (95\% increase) with an average net production of $42.6 \mu \mathrm{g}$ glu. equ. $\mathrm{cm}^{-3}$ wet sed. $\mathrm{h}^{-1}(17.1 \mu \mathrm{gC}$ $\mathrm{cm}^{-3} \mathrm{~h}^{-1}$ ). Concentrations were significantly lower deeper in the sediment underlying mats (10 to $12 \mathrm{~mm}$ ) ( $t$-test, $\mathrm{n}=8, \mathrm{p}<0.05$ ) and did not show variations due to exposure (Table 2a). The EDTA-soluble carbohydrates, extracted from the sediment pellet, increased significantly in the surface biofilm, on average by $31 \%$ (Fig. 3c, Table 2a). The average net production was $28.8 \mu \mathrm{g}$ glu. equ. $\mathrm{cm}^{-3}$ wet sed. $\mathrm{h}^{-1}\left(11.6 \mu \mathrm{g} \mathrm{C} \mathrm{cm}^{-3} \mathrm{~h}^{-1}\right)$. At 10 to $12 \mathrm{~mm}$ depth EDTA-extracted carbohydrates concentrations were comparable to surface concentrations but without an increase during the emerged period. In the 2 emerged periods which fell largely in the dark, increases in all 3 fractions of carbohydrates in the sediment surface were comparable to increases in carbohydrates in daytime periods of emersion (Fig. $3 a, b, c)$.

The phytopigments, chl $a$ and pheopigments, did not show significant increases in the 0 to $2 \mathrm{~mm}$ or in the 10 to $12 \mathrm{~mm}$ layer (Fig. 3d,e, Table 2a). Only chl a decreased significantly with depth ( $t$-test, $\mathrm{n}=8, \mathrm{p}<0.01$ ). Carbohydrate fractions per unit chl a increased over the emerged period, indicating that the increases in carbohydrates were not due to variations in chl a concentrations. The average net productions of carbohydrates per unit chl a were 216, 487 and $277 \mathrm{ng}$ glu. equ.
HMW carbohydrates ( $\mu \mathrm{g}$ glu. equ. $\mathrm{cm}^{-3}$ wet sed.)

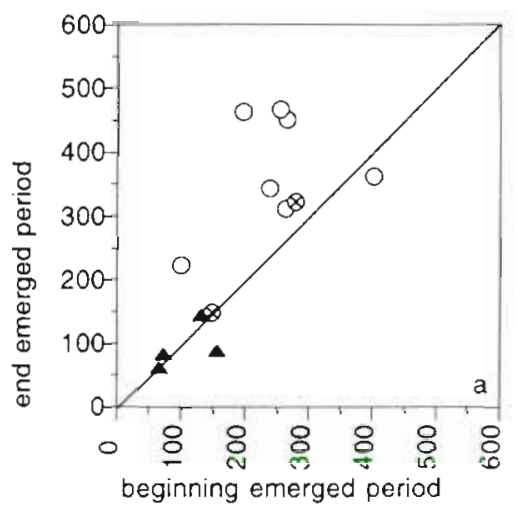

chlorophyll-a $\left(\mu \mathrm{g} \mathrm{cm} \mathrm{cm}^{-3}\right.$ wet sed.)

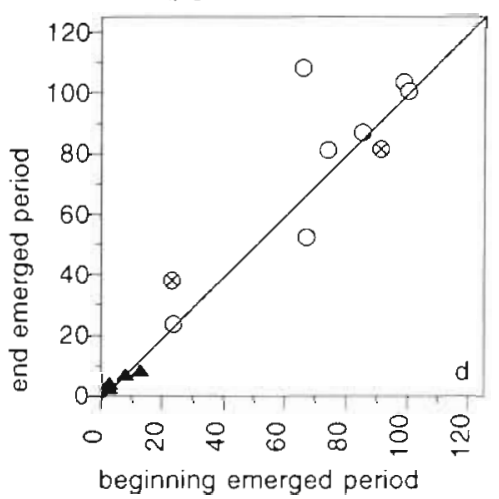

LMW carbohydrates ( $\mu$ g glu. equ. $\mathrm{cm}^{-3}$ wet sed.)

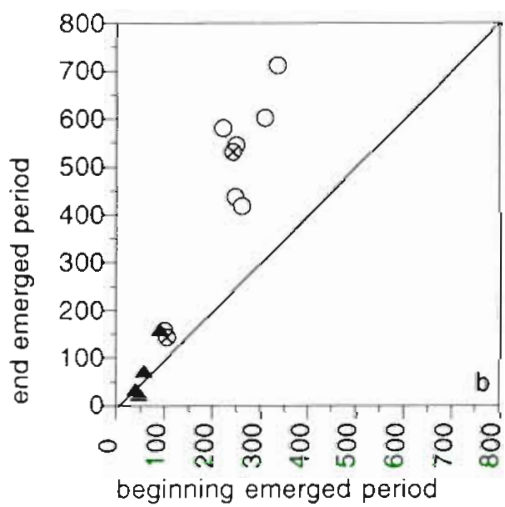

pheopigment ( $\mu \mathrm{g} \mathrm{cm}^{-3}$ wet sed.)

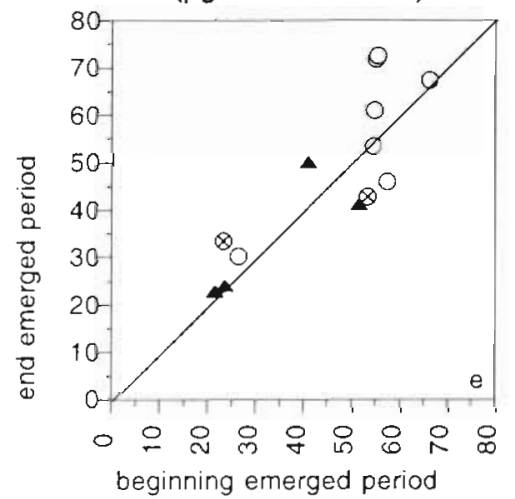

EDTA-extracted carbohydrates ( $\mu$ g glu. equ. $\mathrm{cm}^{-3}$ wet sed.)

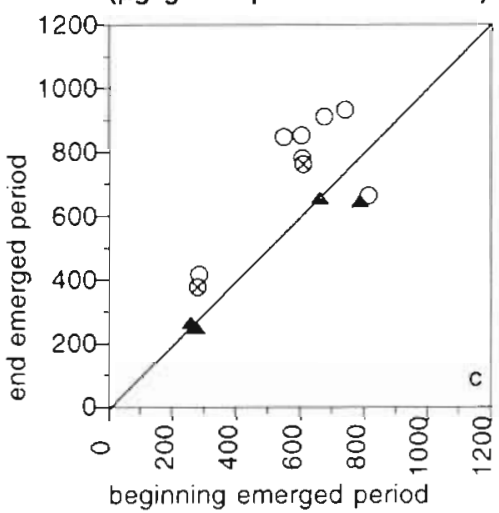

Fig. 3. Comparisons of concentrations of different fractions of $(a, b, c)$ carbohydrates and $(d, e)$ phytopigments at the beginning of the emerged period with their concentrations at the end of the emerged period. Circles: comparisons at 0 to $2 \mathrm{~mm}(\mathrm{n}=9,7$ daytime $[0]$ and 2 nighttime $[\otimes]$ emerged periods); ( $\mathbf{A}$ comparisons at the reference depth 10 to $12 \mathrm{~mm}$ $(n=4)$. For explanation of the function of diagonal line see Fig. 2 legend 

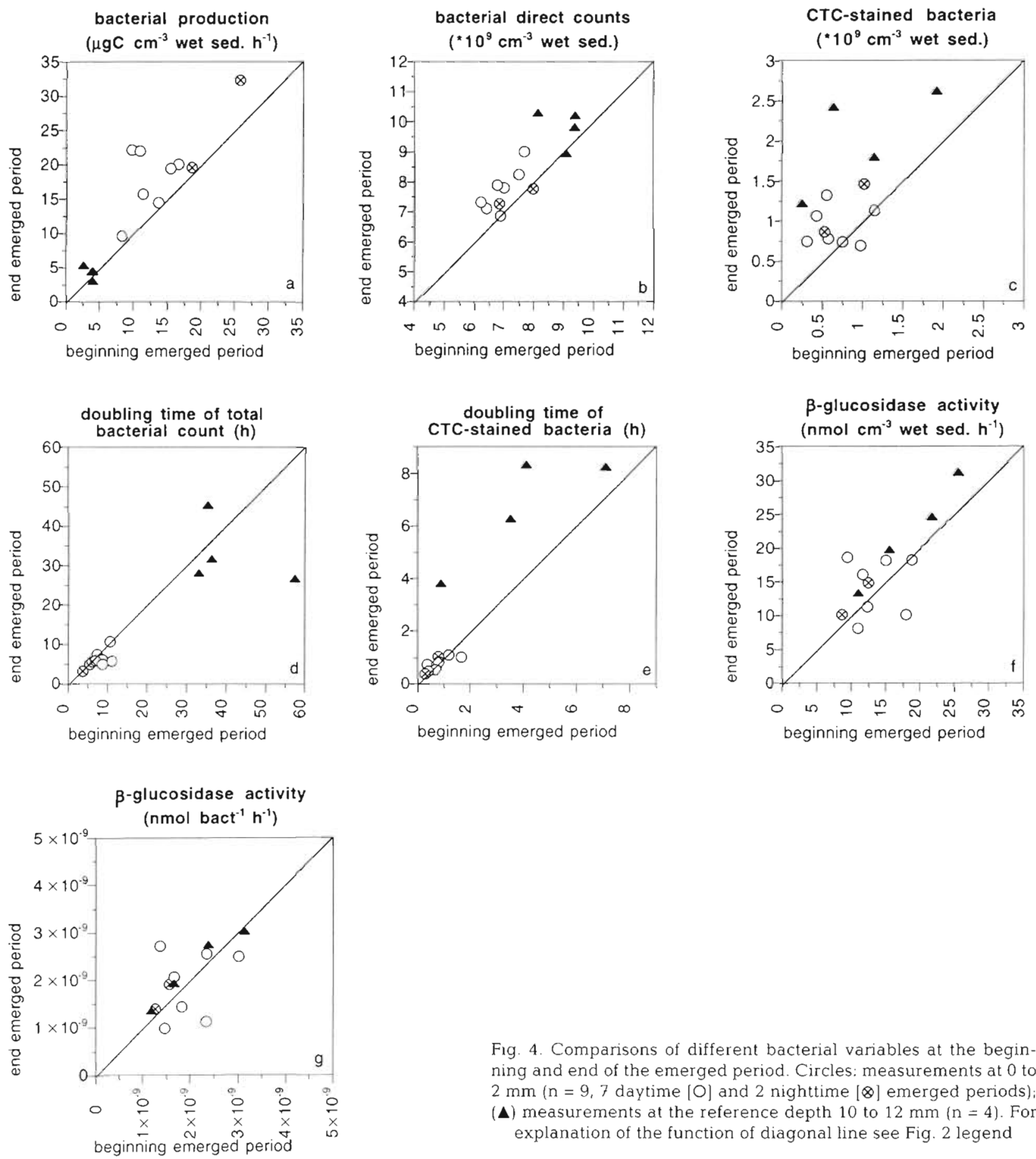

Fig. 4. Comparisons of different bacterial variables at the beginning and end of the emerged period. Circles: measurements at 0 to $2 \mathrm{~mm}(\mathrm{n}=9,7$ daytime $[0]$ and 2 nighttime $[\otimes]$ emerged periods); (A) measurements at the reference depth 10 to $12 \mathrm{~mm}(\mathrm{n}=4)$. For explanation of the function of diagonal line see Fig. 2 legend

$\mu \mathrm{g} \mathrm{chl} \mathrm{c}^{-1} \mathrm{~h}^{-1}$ for water-extracted HMW carbohydrates, LMW carbohydrates and EDTA-extracted carbohydrates respectively, with maximum rates around $850 \mathrm{ng}$ glu. equ. $\mu \mathrm{g} \mathrm{chl}^{-1} \mathrm{~h}^{-1}$ for all 3 fractions.

BBP increased significantly during the emerged period (Fig. 4a, Table 2a). Bacterial production deeper in the sediment ( 10 to $12 \mathrm{~mm}$ ) was much lower than in the surface layer ( $t$-test, $n=8, p<0.01$ ) and did not change (Table 2a). Bacterial abundance varied only slightly (Fig. 4b) but nevertheless increased significantly (Table 2a). This increase (on average 10\%) might partly, although not significantly, have been due to changes in water content mentioned earlier. Densities ranged between 6 and $8.3 \times 10^{9}$ cells $\mathrm{cm}^{-3}$ wet sed. (sediment) in the surface layer of the diatom mat ( 0 to $2 \mathrm{~mm}$ ). Deeper down (10 to $12 \mathrm{~mm}$ ) densities were 
higher ( $t$-test, $\mathrm{n}=8, \mathrm{p}<0.01$ ), around 8 to $9 \times 10^{9}$ cells $\mathrm{cm}^{-3}$ wet sed. At this reference depth no increase was found during the exposure (Table 2a). CTC-stained bacteria represented 4 to $20 \%$ of the total count in the sediment surface layer. Variations in their numbers were significantly determined by tidal exposure, with a tendency for an increase during the emerged period (Fig. 4c, Table 2a). Deeper in the sediment (10 to $12 \mathrm{~mm}$ ) the abundance of CTC-stained bacteria was significantly higher ( $t$-test, $\mathrm{n}=8, \mathrm{p}<0.01)$, amounting to up to $30 \%$ of the total count, and, moreover, abundance increased significantly (Table 2a). No significant changes in doubling times of total or of CTC-stained bacterial counts in the sediment surface were found (Fig. $4 \mathrm{~d}, \mathrm{e}$, Table 2a). Doubling times were on average $0.7 \mathrm{~h}$ for CTC-stained bacteria and $7 \mathrm{~h}$ for all counted bacteria, assuming that they were all dividing. At 10 to $12 \mathrm{~mm}$ depth doubling times were substantially longer and for CTC-stained bacteria they even increased over the emerged period (Table 2a, Fig. 4e), which is a consequence of the unexplained increase in these respiring bacteria.

The variations in $\beta$-glucosidase activity lacked a significant emersion/submersion pattern (Fig. 4f, Table 2a). Total activity significantly increased with depth (up to $31 \mathrm{nmol} \mathrm{cm}^{-3}$ wet sed. $\mathrm{h}^{-1}$; t-test, $n=8, \mathrm{p}<0.01$ ). At 10 to $12 \mathrm{~mm}$ depth the enzyme activity showed a small but significant increase over the emerged period (Fig. 3f, Table 2a). The enzyme activity per bacterium did not change during the emerged period (Fig. $4 \mathrm{~g}$, Table 2a) but significantly increased with depth ( $t$-test, $\mathrm{n}=8, \mathrm{p}<0.05$ ). As for carbohydrates, changes in the microbial variables were not related to the time of emersion. During nighttime as well as daytime, changes (increases) over the exposure period were comparable (Fig. 4). Therefore results obtained in daytime and nighttime emerged periods were pooled in the statistical analyses.

\section{Changes during the submerged period}

Over the submerged period a significant decreasing trend in water-extracted carbohydrate fractions and CTC-stained bacteria in the sediment surface layer was observed, which was not reflected by significant changes in the phytopigments (Table 2b). Bacterial production also changed, but reductions were not statistically significant (Table 2b). EDTA-extracted carbohydrates, bacterial total counts, doubling time and $\beta$ glucosidase activity did not change significantly. Mean differences and standard deviations over the submerged period were comparable to the values established over the 5 to $6 \mathrm{~h}$ lasting emerged period (Table $2 \mathrm{a}, \mathrm{b})$. At the reference depth, 10 to $12 \mathrm{~mm}$, no significant changes were assessed except for a significant decrease in the $\beta$-glucosidase activity (data not shown in Table 2b).

Table 3. Matrix of Pearson's correlation coefficients between biochemical and microbial variables in the 0 to $2 \mathrm{~mm}$ surface layer of the diatom-inhabited intertidal mudflat $(\mathrm{n}=18)$, with the significant relations obtained in the 10 to $12 \mathrm{~mm}$ reference layer $(\mathrm{n}=8)$ indicated by $/ \cdot$ or $/ \cdots$. Values of $\mathrm{r}$ significant at $\mathrm{p}<0.05, \cdots p<0.01$. Only the correlation coefficients in bold remained significant after Bonferroni adjustment. Ranges in measurements of the different variables are expressed per $\mathrm{cm}^{-3}$ wet sediment; numbers in parentheses represent the concentrations expressed in $\mu \mathrm{g} \mathrm{g}^{-1}$ dry sediment

\begin{tabular}{|c|c|c|c|c|c|c|c|c|c|}
\hline Variable & $\begin{array}{l}\text { Range in } \\
0 \text { to } 2 \mathrm{~mm}\end{array}$ & Chl a & $\begin{array}{l}\text { Pheo- } \\
\text { pigm. }\end{array}$ & $\begin{array}{l}\text { HMW } \\
\text { carb. }\end{array}$ & $\begin{array}{l}\text { LMW } \\
\text { carb. }\end{array}$ & $\begin{array}{l}\text { EDTA } \\
\text { carb. }\end{array}$ & $\begin{array}{l}\text { Bact. } \\
\text { prod. }\end{array}$ & $\begin{array}{l}\text { Total } \\
\text { bact. }\end{array}$ & $\begin{array}{l}\text { CTC-stained } \\
\text { bact. }\end{array}$ \\
\hline $\begin{array}{l}\mathrm{Chl} \mathrm{a} \\
\left(\mu \mathrm{g} \mathrm{cm} \mathrm{cm}^{-3} \text { wet sed.) }\right.\end{array}$ & $\begin{array}{l}22.8-108.4 \\
(74.7-142.3)\end{array}$ & & & & & & & & \\
\hline $\begin{array}{l}\text { Pheopigment } \\
\text { ( } \mu \mathrm{g} \mathrm{cm}^{-3} \text { wet sed.) }\end{array}$ & $\begin{array}{l}23.0-72.5 \\
(53.5-94.1)\end{array}$ & $0.893 \cdot / \cdot \cdot$ & & & & & & & \\
\hline $\begin{array}{l}\text { Water-extr. HMW carb. } \\
\left(\mu \mathrm{cm}^{-3} \text { wet sed. }\right)\end{array}$ & $\begin{array}{l}98.2-467.8 \\
(222-769)\end{array}$ & $0.707^{\circ /} /$ & $0.668 \cdots / \cdots$ & & & & & & \\
\hline $\begin{array}{l}\text { Water-extr. LMW carb. } \\
\left(\mu \mathrm{cm}^{-3} \text { wet sed.) }\right.\end{array}$ & $\begin{array}{l}98.3-712.4 \\
(211-1151)\end{array}$ & $0.693 \cdot \cdot$ & $0.601 \cdot \cdot$ & $0.857^{\circ}$ & & & & & \\
\hline $\begin{array}{l}\text { EDTA-extr. carb. } \\
\left(\mu g \mathrm{~cm}^{-3} \text { wet sed. }\right)\end{array}$ & $\begin{array}{l}276.1-933.4 \\
(628-1468)\end{array}$ & $0.842 \cdot / \cdot$ & $0.816 \cdot / \cdot \cdot$ & $0.857 \cdot \cdot / \cdot \cdot$ & $0.861 *$ & & & & \\
\hline $\begin{array}{l}\text { Bacterial production. } \\
\left(\mu \mathrm{C} \mathrm{cm}^{-3} \text { wet sed. } \mathrm{h}^{-1}\right)\end{array}$ & $8.2-32.3$ & 0.039 & -0.22 & 0.102 & 0.261 & 0.052 & & & \\
\hline $\begin{array}{l}\text { Bacterial total count } \\
\left(\mathrm{n} \times 10^{9} \mathrm{~cm}^{-3} \text { wet sed. }\right)\end{array}$ & $6.2-9.0$ & 0.339 & 0.280 & 0.341 & $0.516^{\circ}$ & $0.288 /^{\circ}$ & 0.328 & & \\
\hline $\begin{array}{l}\text { CTC-stained bacteria } \\
\left(\mathrm{n} \times 10^{9} \mathrm{~cm}^{-3} \text { wet sed.) }\right.\end{array}$ & $0.3-1.5$ & -0.144 & -0.024 & -0.049 & 0.056 & -0.023 & 0.233 & $0.482^{\circ}$ & \\
\hline $\begin{array}{l}\beta \text {-glucosidase activity } \\
\left(\text { nmol } \mathrm{cm}^{-3} \text { wet sed. } \mathrm{h}^{-1}\right)\end{array}$ & $8.3-188$ & -0.352 & $-0.180 /{ }^{\circ}$ & $-0.247 / \cdot \cdot$ & -0.208 & $-0.190 /{ }^{* *}$ & $-0.513^{\circ}$ & -0.328 & 0.114 \\
\hline
\end{tabular}


Table 4. Multiple regressions with the changes in bacterial production over the emerged and submerged periods as the dependent variable and changes in bacterial abundance (total and CTC-stained bacteria: $\triangle B N$ and $\triangle C T C$-st. bact.), in $\beta$-glucosidase activity ( $\triangle \beta$-gluc. act.) and in the water-extracted LMW and HMW carbohydrates ( $\triangle \mathrm{LMW}$ carb., $\triangle H M W$ carb.) as independents. Values used were from the 0 to $2 \mathrm{~mm}$ layer only. C: coefficient; SE: standard error; SC: standardized coefficient; ns: not significant

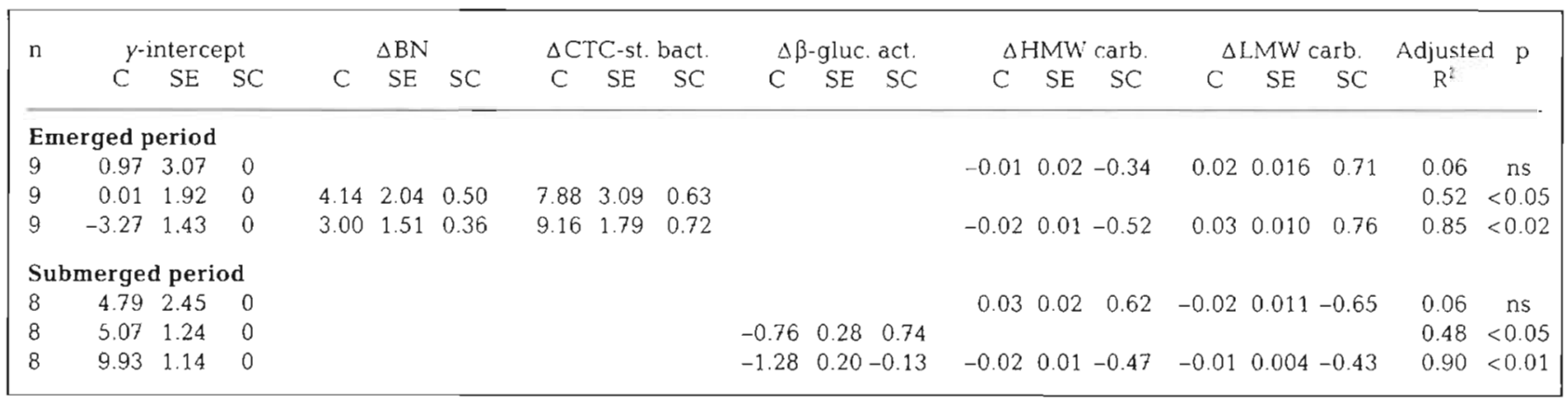

\section{Relationships}

The different carbohydrate fractions in the surface sediment showed strong interrelationships (Table 3) which were, except for the correlation between the EDTA-extracted fraction and HMW carbohydrates, not found deeper in the sediment. Significant relations between phytopigments (chl a and pheopigment) and carbohydrates in the 0 to $2 \mathrm{~mm}$ layer emphasize the linkage of carbohydrates with benthic primary producers. Deeper in the sediment $(10$ to $12 \mathrm{~mm}$ ) pheopigments and LMW carbohydrates were no longer significantly related, while the other relationships with pheopigments in this depth layer remained significant. Between the microbial and biochemical variables 4 significant relations occurred: 1 in the sediment surface layer between bacterial total count and LMW carbohydrates and 3 deeper in the sediment between $\beta$-glucosidase activity and HMW carbohydrates, EDTA-extracted carbohydrates, pheopigments. The $\beta$-glucosidase activity decreased significantly with increasing BBP in the 0 to $2 \mathrm{~mm}$ layer. Deeper in the sediment (10 to $12 \mathrm{~mm}$ ) this relation tended to be positive although not significant $(\mathrm{r}=$ $0.40, \mathrm{n}=8$ )

After pooling the data of the 0 to 2 and 10 to $12 \mathrm{~mm}$ depth layers significant positive relations between BBP and chl $a(r=0.62, n=26, p<0.05)$, and LMW carbohydrates $(\mathrm{r}=0.64, \mathrm{n}=26, \mathrm{p}<0.05)$ and EDTAextracted carbohydrates $(r=0.62, n=26, p<0.05)$ and a negative relation with $\beta$-glucosidase activity $(\mathrm{r}=$ $-0.59, \mathrm{n}=26, \mathrm{p}<0.05$ ) were found with Bonferroni adjustment. $\beta$-glucosidase activity was also negatively related to EDTA-extracted carbohydrates ( $\mathrm{r}=-0.74$, $\mathrm{n}$ $=26, p<0.01$ Bonferroni adjusted) .

In Table 4 results of multiple regressions are shown in which the net change of the variable BBP (dependent) is related to net changes of bacterial numbers, enzyme activities and carbohydrates in the surface sediment. The regressions showed the importance of the net changes in water-extracted LMW and HMW carbohydrates for explaining the variations in net $\mathrm{BBP}$ changes during emerged as well as submerged periods. The addition of these carbohydrates as independents to the regression improved the relation by $>30 \%$ (Table 4). Of the variations in the net change in BBP over the emerged period, $85 \%$ could be explained by the variation in net change of total bacterial cells, CTC-stained bacteria and water-extracted carbohydrates. Of the variations in the net change in BBP between submersion and subsequent emersion, $93 \%$ could be explained by the variation in net change of $\beta$ glucosidase activity and water-soluble carbohydrates. Changes in chl a and pheopigment did not improve the regressions. Variation in bacterial production changes during the tidal cycle were not related to net changes in EDTA-extracted carbohydrates.

\section{DISCUSSION}

The main source of water-extracted carbohydrates in the intertidal mudflat in the Ems-Dollard appears to be live diatoms. During our fieldwork diatoms formed a dense mat (100 to $150 \mu \mathrm{m}$ thick) dominated by the motile species of the genera Nitzchia and Navicula (Wiltshire et al. 1998). Diatoms migrated to the surface upon exposure, resulting in an evident change of colour of the sediment to greenish-brown. Movements appeared to be restricted to the upper $200 \mu \mathrm{m}$ horizon of the sediment (Wiltshire et al. 1998). Significant relations of HMW and LMW fractions with chl $a$ in the 0 to $12 \mathrm{~mm}$ layer emphasize the linkage of these carbohydrate fractions with diatoms. The sharp decrease in the concentrations of these carbohydrate fractions with depth coincided with a decrease in chl $a$, which is in accordance with observations by Taylor \& Paterson (1998) 
The fraction of EDTA-extracted carbohydrates showed less specific correlation patterns and dynamics than the water-extracted carbohydrates. Although the EDTA fraction showed a significant relation with HMW and LMW fractions in the upper layer, the fact that EDTA-extracted carbohydrates did not decrease with depth suggests a looser relation with algal photosynthetic activities. However its significant relations with chl a and pheopigment in the upper $12 \mathrm{~mm}$ emphasize its connection with algal matter. This supports the suggestion by Underwood et al. (1995) of a link between EDTA-extracted carbohydrates and senescence of the algal assemblage.

\section{Coupling during the emerged period}

During tidal exposure of diatom-inhabited intertidal mudflats, carbohydrates clearly increased in the sediment surface layer. According to Staats et al. (2000) the production of these carbohydrates is directly related to the primary production of diatoms and thus to light and light dose. However, observed increases in the emerged periods which fell largely in the dark suggest that exposure to light and light dose are apparently not the only factors inducing the increases. Smith \& Underwood (1998) found endogenous rhythms of carbohydrate production in diatom biofilms which were closely synchronized with periods of emersion. Moreover, they showed that dim light, darkness and migration of epipelic diatoms linked to tidal submersion enhanced the EPS production. These findings agree with the carbohydrate increases we found over the emerged periods which fell largely in the dark. Apparently, tidal cycles as well as dark/light cycles play a role in the increases of carbohydrates.

The carbohydrate concentration per unit biomass also increased during the emerged period, most likely due to an increase in carbohydrate production per unit biomass (Serodio et al. 1997, Wetherbee et al. 1998) and not by an accumulation in the absence of overlying water and resuspension (Staats et al. 2000). The net productions of the water-extracted carbohydrates expressed in ng glu. equ. $\mu \mathrm{g} \mathrm{chl} a^{-1} \mathrm{~h}^{-1}$ were in the same range or even exceeded EPS production in English mudflats during tidal flat illumination (Underwood \& Smith 1998). This is the first time such carbohydrate increases have been recorded to coincide with an increase in benthic heterotrophic bacterial production. It could be argued that the HMW carbohydrate pool contributed to the increases in LMW carbohydrates, which comprise readily available molecules for bacteria (Sundh 1992, De Winder et al. 1999). Saccharolytic enzymes are probably active in both pools, cleaving oligosaccharides into monosaccharides in the LMW pool. The strong increase in LMW carbohydrates during the emerged period could also have been due to direct exudation of photoassimilates comprising simple sugars (Williams 1990, Underwood et al. 1995). Although unlikely, it cannot be excluded that rupture of cells during the extraction procedure may also have released LMW carbohydrates from algal cells. The increase in the LMW carbohydrate pool was, however, not reflected by an increase in potential MUF- $\beta$-glucoside hydrolysis. The $\beta$-glucosidase activity was stable throughout the tidal cycle in the sediment surface and was not related to changes in the HMW or LMW carbohydrate pools. This implies that there were no indications of a positive control of $\beta$-glucosidase activity by its substrate, as found by Boetius \& Lochte (1996) in deep-sea sediments. On the contrary, inhibition of $\beta$ glucosidase activity in the mat appeared more likely. The fact that the potential $\beta$-glucosidase activity increased with depth, where hydrolyzable carbohydrates sharply dropped in concentration, suggests that enzyme production is inhibited in the sediment surface layer compared to its production at the reference depth, possibly by end-product inhibition. The inhibition concept was further supported by the observation that the enzyme activity in sediment patches without a visible diatom mat, adjacent to mat patches, was also higher than in the mat itself, where hydrolyzable carbohydrate concentrations were significantly higher than outside (Van Duyl et al. 2000). However, it should be mentioned here that we did not measure actual turnover rates of the substrate. Our range in potential $\beta$-glucosidase activities ( 8.1 to $31.3 \mathrm{nmol} \mathrm{cm} \mathrm{cm}^{-3} \mathrm{~h}^{-1}$ ) was

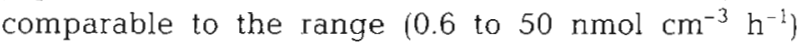
found in other shallow-water sediments (King 1986, Meyer-Reil 1986, Köster et al. 1997). The average activity per cell in the sediment $\left(1.9 \pm 0.6 \mathrm{amol} \mathrm{cell}^{-1}\right.$ $\mathrm{h}^{-1}$ ) was close to the average $\beta$-glucosidase activity of pelagic marine bacteria in the exponential growth phase (e.g. Martinez et al. 1996). The negative relationship between $\beta$-glucosidase activity and $B B P$ in the mat suggests that the bacteria most responsive to the short-term variations in LMW carbohydrates are probably not $\beta$-glucosidase-producing bacteria, but fastgrowing species which do not produce such enzymes themselves. BBP and carbohydrate concentrations were not related in the mat. For the HMW carbohydrates this is not surprising because the HMW compounds are only available to bacteria after enzymatic cleavage to oligo/monosaccharides, which, at least for $\beta$-glucosidase, appeared to be inhibited. The lack of a direct coupling of BBP with LMW carbohydrates suggests that this pool as a whole did not control BBP. Its composition should be defined in more detail in order to establish significant relations between BBP and carbohydrates at tidal cycle time scales. That the high con- 
centrations of water-extracted carbohydrates nevertheless contributed to the enhanced BBP in mats may be deduced from the facts that a positive relation was found between depth-pooled data of BBP and LMW carbohydrates and that BBP in mats was high compared to productions in intertidal flats without such diatom mats (Van Duyl \& Kop 1990, Sander \& Kalff 1993).

Besides BBP, the total numbers of bacteria and of CTC-stained bacterial cells also increased in the mat during the emerged period. It is assumed that only part of the bacterial population can deposit sufficient insoluble fluorescent formazan for detection of cells under the epifluorescence microscope, and moreover CTC tends to inhibit bacterial production (Ullrich et al. 1996, Cook \& Garland 1997). This implies that the method probably underestimates the total number of respiring bacteria, but nevertheless provides information with respect to relative changes in CTC-stained cells. The percentage of the total count that was respiring bacteria ( 4 to $30 \%$ ) was in the same range as literature values for CTC applications in different habitats, e.g. Schaule et al. (1993), Gasol et al. (1995), Del Giorgio et al. (1997). Changes over the emerged period may have been due to changes in size of the bacteria (Gasol et al. 1995) in response to substrate changes in the sediment surface. The higher abundance of CTC-stained cells deeper in the sediment and their significant increases during the emerged period cannot be explained on the basis of the data presented. Significant tidal variations in carbohydrate concentrations, bacterial production and total abundance did not occur at 10 to $12 \mathrm{~mm}$ depth. At least for these variables 10 to $12 \mathrm{~mm}$ was a suitable reference depth, at which the effects of shortterm tidal illumination/exposure as observed in the surface layer were absent.

Doubling times of CTC-stained bacteria and of total direct counts of bacteria did not significantly decrease over the emerged period in the sediment surface layer. The production per cell, either a CTC-stained cell or a cell of the total count, did not increase. So the actual number of bacteria must have increased during the emerged period to explain the increased bacterial production. Del Giorgio et al. (1997) came to a similar interpretation for changes in bacterioplankton growth. The net increase of cells may have been attained by cell production and/or by reduced bacterivory. Although bacterivory can be high in intertidal sediments (Epstein 1997), cell production is most likely considering the positive relation between bacterial abundance and LMW carbohydrates and the significant increases in these carbohydrates during the emerged period. Significant relationships between cell number and uptake of glucose have been reported for sandy sediments (Meyer-Reil et al. 1978). Moreover, amendments of monosaccharides to sediments have been shown to increase bacterial production and abundance in sediments (e.g. Meyer-Reil et al. 1978, 1980, Boetius \& Lochte 1996). With glucose turnover times in sediments of 2 to $10 \mathrm{~min}$ (Sawyer \& King 1993), response rates of bacteria to glucose might be sufficiently rapid to react to changes in supply within hours. This might explain the rapid increases in bacterial production during the emerged period. Net changes in LMW and HMW carbohydrates with net changes in bacterial abundance (total count and CTCstained cells) accounted for $85 \%$ of the variance in net bacterial production increases. The regression clearly demonstrates the short-term coupling of bacterial production with the extracellularly released compounds by diatoms in the diatom mat. The LMW carbohydrates secreted during the emerged period are apparently better available to bacteria than the bulk LMW pool that is present at the beginning of the emerged period. It is evident that the variations in waterextracted carbohydrates play an important role in the bacterial dynamics.

It is generally assumed that the EDTA-extracted carbohydrates are mainly associated with capsular material of organisms (Decho 1990, Decho \& Lopez 1993). Because most benthic bacteria secrete capsules, the increase in bacterial cells during the emerged period may have contributed to the net increase in EDTAextracted carbohydrates. Relations of EDTA-extracted carbohydrates with bacteria were indeed found (at 10 to $12 \mathrm{~mm}$ depth in the sediment), but relations with bacterial activities could not be established in the 0 to 2 and 10 to $12 \mathrm{~mm}$ depth layers. EDTA-extracted carbohydrates are apparently less available for bacteria than the water-extracted carbohydrates.

\section{Coupling during the submerged period}

During the submerged period (= dark period for the algal mat) a significant change in HMW carbohydrates and decrease in LMW carbohydrates concurred with a significant change in bacterial production and a significant drop in the numbers of CTC-stained bacterial cells. The fact that carbohydrates, BBP and CTCstained bacteria at the reference depth did not decrease may indicate that the decreases in the surface layer are mainly due to solubilization of water-extracted sugars in overlying waters (which would agree with the findings of Decho 1990) and/or resorption of sugars by diatoms (which would agree with the findings of e.g. Admiraal \& Pelletier 1980). The decrease in these sugars may have induced the drop in BBP and CTC-stained bacteria. However, the fact that we found a significant relation between variations in net change of bacterial production and variations in net change of 
$\beta$-glucosidase activity and water-extracted carbohydrates over the submerged period may also point to a microbiologically mediated disappearance of carbohydrates. In the absence of net production of carbohydrates during the submerged period, water-extractable sugar concentrations decline, reaching levels at which the bacteria may become dependent on enzyme activity for their demand of carbon from the LMW and HMW carbohydrate pools. This may explain the role of $\beta$-glucosidase activity in the regression. The negative relation between the changes in BBP and the decreases in water-soluble carbohydrates indicates that relatively large decreases in LMW and HMW carbohydrates coincide with modest changes in BBP. Particularly the large increases in LMW carbohydrates in the emerged periods are usually followed by relatively large decreases during the submerged period. This points to the labile nature of the LMW carbohydrates accumulating during the emerged period and their bioavailability to bacteria.

The particle-associated and particulate variables such as EDTA-extracted carbohydrates, phytopigments and total bacterial standing stock did not significantly change during the submerged period (Table $2 \mathrm{~b}$ ). This suggests that losses of these components due to resuspension were minimal; in contrast, resuspension can be substantial in the Ems-Dollard estuary (De Jonge \& van Beusekom 1995). The stability of mats may have prevented resuspension. However, Wiltshire et al. (1998) demonstrated erosion of the diatom mat with respect to phytopigments in the 0 to $200 / 400 \mu \mathrm{m}$ depth layer during submersion. Whether this actually resulted in a net decrease over a full submerged period is unknown. If it did, we may have missed decreases in phytopigments in the surface microlayer, because we sampled a much thicker depth interval (0 to $2 \mathrm{~mm}$ layer)

\section{Conclusions}

There is a close, but indirect coupling of heterotrophic bacterial production. with water-soluble saccharide secretions by primary producers in diatominhabited intertidal sediments over the tidal cycle. Neither water-extracted carbohydrates over the emerged and submerged periods nor potential $\beta$-glucosidase activity over the submerged period controlled bacterial production, but changes in these variables over the respective periods contributed substantially to the explanation of the variations in bacterial production changes. Heterotrophic microbial dynamics is apparently tightly coupled to labile secretions of primary producers in mats. It was demonstrated that EDTA-extracted carbohydrates did not influence tidal variations in bacterial dynamics
Acknowledgements. We thank the crew of the RV 'Navicula' for their support during the fieldwork. J. van der Meer is acknowledged for statistical advice. B.d.W. was funded by the Dutch NWO programm BOA on intertidal areas. The work was in part supported by the EU-MAST programm INTRMUD (contract number MAS3-CT95-0022) in the case of U.W. This is NIOZ publication no. 3401 and NIOO-CEMO publication no. 2131 .

\section{LITERATURE CITED}

Admiraal W (1984) The ecology of estuarine sediment-inhabiting diatoms. Prog Phycol Res 3:269-322

Admiraal $W$, Pelletier $H(1980)$ Influence of seasonal variations of temperature and light on the growth rate of cultures and natural populations of intertidal diatoms. Mar Ecol Prog Ser 2:35-43

Billen G (1982) Modelling the processes of organic matter degradation and nutrient recycling in sedimentary systems. In: Nedwell DB, Brown CM (eds) Sediment microbiology. Academic Press, London, p 15-52

Boetius A (1995) Microbial hydrolytic enzyme activities in deep-sea sediments. Helgol Meeresunters 49:177-187

Boetius A, Lochte K (1994) Regulation of microbial enzymatic degradation of organic matter in deep sea sediments. Mar Ecol Prog Ser 104:299-307

Boetius $A_{1}$, Lochte K (1996) Effect of organic enrichments on hydrolytic potentials and growth of bacteria in deep-sea sediments. Mar Ecol Prog Ser 140:239-250

Cook KL, Garland JL (1997) The relationship between electron transport activity as measured by CTC reduction and $\mathrm{CO}_{2}$ production in mixed microbial communities. Microb Ecol 34:237-247

Danovaro R, Fabiano M, Della Croce N (1993) Labile organic matter and microbial biomasses in deep-sea sediments (Eastern Mediterranean Sea). Deep-Sea Res 40:953-965

Decho AW (1990) Microbial exopolymer secretions in ocean environments: their role(s) in food webs and marine processes. Oceanogr Mar Biol Annu Rev 28:73-153

Decho AW, Lopez GR (1993) Exopolymer microenvironments in microbial flora: multiple and interactive effects on trophic relationships. Limnol Oceanogr 38:1633-1645

Decho AW, Moriarty DJW (1990) Bacterial exopolymer utilization by a harpacticoid copepod: a methodology and results. Limnol Oceanogr 35:1039-1049

De Jonge VN, van Beusekom JEE (1995) Wind- and tideinduced resuspension of sediment and microphytobenthos from tidal flats in the Ems estuary. Limnol Oceanogr 40 $766-778$

Del Giorgio PA, Prairie YT, Bird DF (1997) Coupling between rates of bacterial production and the abundance of metabolically active bacteria in lakes, enumerated using CTC reduction and flow cytometry. Microb Ecol 34:144-154

De Winder B, Staats N, Stal LJ, Paterson DM (1999) Carbohydrate secretion by phototrophic communities in tidal sediments. J Sea Res 42:131-146

Epstein SS (1997) Microbial food webs in marine sediments. I Trophic interactions and grazing rates in two tidal flat communities. Microb Ecol 34:188-189

Gasol JM, Del Giorgio PA, Massana R, Duarte CM (1995) Active versus inactive bacteria: size-dependence in a coastal marine plankton community. Mar Ecol Prog Ser 128:91-97

Herbert D, Phipps PJ, Strange RE (1971) Chemical analysis of microbial cells. In: Norris JR, Ribbons DW (eds) Methods in microbiology. Academic Press, London, p 209-344 
Herndl GJ, Peduzzi P (1989) Potential microbial utilization rates of sublittoral gastropod mucus trails. Limnol Oceanogr 34:780-784

Hobbie JE, Daley RJ, Jasper S (1977) Use of nuclepore filters for counting bacteria by fluorescence microscopy. Appl Environ Microbiol 33:1225-1228

Hoppe HG (1983) Significance of exoenzymatic activities in the ecology of brackish water: measurements by means of methylumbelliferyl-substrates. Mar Ecol Prog Ser 11. $299-308$

King GM (1986) Characterization of $\beta$-glucosidase activity in intertidal marine sediments. Appl Environ Microbiol 51. $373-380$

Kirchman DL, Newell SY, Hodson RE (1986) Incorporation versus biosynthesis of leucine: implications for measuring rates of protein synthesis and biomass production by bacteria in marine systems. Mar Ecol Prog Ser 32:47-59

Köster M, Dahlke S, Meyer-Reil LA (1997) Microbiological studies along a gradient of eutrophication in a shallow coastal inlet in the southern Baltic Sea (Nordrügensche Bodden). Mar Ecol Prog Ser 152:27-39

Ljungdahl LG, Eriksson KE (1985) Ecology of microbial cellulose degradation. Adv Microb Ecol 8:237-299

Martinez J, Smith DC, Steward GF, Azam F (1996) Variability in ectohydrolytic enzyme activities of pelagic marine bacteria and its significance for substrate processing in the sea. Aquat Microb Ecol 10:223-230

Meyer-Reil LA (1986) Measurement of hydralytic activity and incorporation of dissolved organic substrates by microorganisms in marine sediments. Mar Ecol Prog Ser 31: $143-149$

Meyer-Reil LA (1990) Microorganisms in marine sediments: considerations concerning activity measurements. Arch Hydrobiol (Beih Ergebn Limnol) 34:1-6

Meyer-Reil LA (1994) Microbial life in sedimentary biofilms the challenge to microbial ecologists. Mar Ecol Prog Ser 112:303-311

Meyer-Reil LA, Bölter M, Dawson R, Liebezeit G, Szwerinski H, Wolter K (1980) Interrelationships between microbiological and chemical parameters of sandy beach sediments, a summer aspect. Appl environ Microbiol 39 $797-802$

Meyer-Reil LA, Dawson R, Liebezeit G, Tiedge $H$ (1978) Fluctuations and interactions of bacterial activity in sandy beach sediments and overlying waters. Mar Biol 48 . $161-171$

Moriarty DJW (1990) Techniques for estimating bacterial growth rates and production of biomass in aquatic environments. In: Grigorova R, Norris JK (eds) Methods in microbiology. Academic Press, London, p 211-234

Moriarty DJW, Pollard PC (1981) DNA synthesis as a measure of bacterial productivity in seagrass sediments. Mar Ecol Prog Ser 5:151-156

Paerl HW, Bebout BM, Joye SB (1993) Microscale characterization of dissolved organic matter production and uptake in marine microbial mat communities. Limnol Oceanogr 38:1150-1161

Paterson DM (1989) Short-term changes in the erodibility of intertidal cohesive sediments related to the migratory behaviour of epipelic diatoms. Limnol Oceanogr 34: 223-234

Paterson DM, Yallop ML, George C (1994) Spatial variability in sediment erodibility on the island of Texel. In: Krumbein WE, Paterson DM, Stal LJ (eds) Biostabilization of sediments. Bibliotheks und Informationssystem der Carl von Ossietzky Universität Oldenburg, Oldenburg, p $107-120$
Poremba K, Hoppe H-G (1995) Spatial variation of benthic microbial production and hydrolytic enzymatic activity down the continental slope of the Celtic Sea. Mar Ecol Prog Ser 118:237-245

Rice WR (1989) Analyzing tables of statistical tests. Evolution 43:223-225

Rodriguez GG, Phipps D, Ishiguro K, Ridgway HF (1992) Use of a fluorescent redox probe for direct visualization of actively respiring bacteria. Appl Environ Microbiol 58 : $1801-1808$

Sander BC, Kalff J (1993) Factors controlling bacterial production in marine and freshwater sediments. Microb Ecol $26: 79-99$

Sawyer TE, King GM (1993) Glucose uptake and end product formation in an intertidal marine sediment. Appl Environ Microbiol 59:120-128

Schaule G, Flemming HC, Ridgway HF (1993) Use of 5cyano-2,3-ditolyl tetrazolium chloride for quantifying planktonic and sessile respiring bacteria in drinking water. Appl Environ Microbiol 59:3850-3857

Serodio J, de Silva JM, Catarino F (1997) Nondestructive tracing of migratory rhythms of intertidal benthic microalgae using in vivo chlorophyll a fluorescence. J Phycol 33: $542-553$

Simon M, Azam F (1989) Protein content and protein synthesis rates of planktonic marine bacteria. Mar Ecol Prog Ser 51:201-213

Smith DJ, Underwood GJC (1998) Exopolymer production by intertidal epipelic diatoms. Limnol Oceanogr 43 $1578-1591$

Somville M, Billen G (1983) A method for determining exoproteolytic activity in natural waters. Limnol Oceanogr 28 : $190-193$

Staats N, Stal LJ, de Winder B, Mur LR (2000) Oxygenic photosynthesis as the driving process in exopolysaccharide production of benthic diatoms. Mar Ecol Prog Ser (in press)

Sundh I (1992) Biochemical composition of dissolved organic carbon-derived from phytoplankton and used by heterotrophic bacteria. Appl Environ Microbiol 58:2938-2947

Taylor IS, Paterson DM (1998) Microspatial variation in carbohydrate concentrations with depth in the upper millimetres of intertidal cohesive sediments. Estuar Coast Shelf Sci $46: 359-370$

Ullrich S, Karrasch B, Hoppe HG, Jeskulke K, Mehrens M (1996) Toxic effects on bacterial metabolism of the redox dye 5-cyano-2,3-ditolyl tetrazolium chloride. Appl Environ Microbiol 62:4587-4593

Underwood GJC, Paterson DM (1993a) Recovery of intertidal benthic diatoms after biocide treatment and associated sediment dynamics. J Mar Biol Assoc UK 73:25-45

Underwood GJC, Paterson DM (1993b) Seasonal changes in diatom biomass, sediment stability and biogenic stabilization in the Severn estuary. J Mar Biol Assoc UK 73: $871-887$

Underwood GJC, Smith DJ (1998) Predicting epipelic diatom exopolymer concentrations in intertidal sediments from sediment chlorophyll-a. Microb Ecol 35:116-125

Underwood GJC, Paterson DM, Parkes RJ (1995) The measurement of microbial carbohydrate exopolymers from intertidal sediments. Limnol Oceanogr 40:1243-1253

Van Duyl FC, De Winder B, Kop AJ, Wollenzien U (2000) Consequences of diatom mat erosion for carbohydrate concentrations and heterotrophic bacterial activities in intertidal sediments of the Ems-Dollard estuary. Cont Shelf Res (in press)

Van Duyl FC, Kop AJ (1990) Seasonal patterns of bacterial 
production and biomass in intertidal sediments of the western Dutch Wadden Sea. Mar Ecol Prog Ser 59 249-261

Van Duyl FC, Kop AJ (1994) Bacterial production in North Sea sediments: clues to seasonal and spatial variations. Mar Biol 120:323-337

Wetherbee R, Lind JL, Burke J, Quatrano RS (1998) The first kiss: establishment and control of initial adhesion by raphid diatorns. J Phycol 34:9-15

Wilkinson L (1989) SYSTAT: The system for statistics. SYSTAT Inc, Evanston, IL

Williams PJleB (1990) The importance of losses during microbial growth: commentary on the physiology, measurement

Editorial responsibility: Otto Kinne (Editor)

Oldendorf/Luhe, Germany and ecology of the release of dissolved organic material Mar Microb Food Webs 4:175-206

Wiltshire KH, Tolhurst T, Paterson DM, Davidson I, Gust G (1998) Pigment fingerprints as markers of erosion and changes in cohesive sediment surface properties in simulated and natural erosion events. In: Black KS, Paterson DM, Cramp A (eds) Sedimentary processes in the intertidal zone. Geol Soc Lond Spec Publ 139:99-114

Yallop ML, De Winder B, Paterson DM, Stal LJ (1994) Comparative structure, primary production and biogenic stabilization of cohesive and non-cohesive marine sediments inhabited by microphytobenthos. Estuar Coast Shelf Sci 39:565-582

Submitted: February 23, 1999; Accepted: August 2, 1999 Proofs received from author(s): December 20, 1999 